(c) American Dairy Science Association, 2005.

\title{
Antibacterial Effect of Caprylic Acid and Monocaprylin on Major Bacterial Mastitis Pathogens
}

\author{
M. K. M. Nair, ${ }^{1}$ J. Joy, ${ }^{1}$ P. Vasudevan, ${ }^{1}$ L. Hinckley,${ }^{2}$ T. A. Hoagland,${ }^{1}$ \\ and K. S. Venkitanarayanan ${ }^{1}$ \\ ${ }^{1}$ Department of Animal Science, Unit 4040, and \\ 2Department of Pathobiology, Unit 4089, University of Connecticut, Storrs 06269
}

\begin{abstract}
Bovine mastitis is the most significant economic drain on the worldwide dairy industry. Concerns regarding poor cure rates, emergence of bacterial resistance, and residues in milk necessitate development of alternative therapeutic approaches to antibiotics for treatment of mastitis. A variety of free fatty acids and their monoglycerides have been reported to exert antimicrobial activity against a wide range of microorganisms. The objective of our study was to examine the efficacy of caprylic acid, a short-chain fatty acid, and its monoglyceride, monocaprylin, to inactivate common mastitis pathogens, including Streptococcus agalactiae, Streptococcus dysgalactiae, Streptococcus uberis, Staphylococcus aureus, and Escherichia coli. Milk samples containing $50 \mathrm{~m} M$ or $100 \mathrm{~m} M$ caprylic acid, and 25 $\mathrm{m} M$ or $50 \mathrm{~m} M$ monocaprylin were inoculated separately with a 3-isolate mixture of each of the 5 pathogens, and incubated at $39^{\circ} \mathrm{C}$. Populations of surviving bacteria were determined at $0 \mathrm{~min}, 1 \mathrm{~min}, 6 \mathrm{~h}, 12 \mathrm{~h}$, and 24 $\mathrm{h}$ of incubation. Both caprylic acid and monocaprylin reduced all 5 pathogens by $>5.0 \log \mathrm{cfu} / \mathrm{mL}$ after $6 \mathrm{~h}$ of incubation. Among the bacterial species tested, Strep. agalactiae, Strep. dysgalactiae, and Strep. uberis were most sensitive, and E. coli was most tolerant to caprylic acid and monocaprylin. Results of this study indicate that caprylic acid and monocaprylin should be evaluated as alternatives or adjuncts to antibiotics as intramammary infusion to treat bovine mastitis.
\end{abstract}

(Key words: caprylic acid, mastitis, monocaprylin)

Abbreviation key: DMSO = dimethyl sulfoxide, TSA = tryptic soy agar.

\section{INTRODUCTION}

Bovine mastitis is the single most important cause of economic loss to the dairy industry, and is character-

Received March 24, 2005.

Accepted June 20, 2005.

Corresponding author: K. S. Venkitanarayanan; e-mail: kumar. venkitanarayanan@uconn.edu. ized by inflammation of the mammary gland, usually caused by a microbial infection. Mastitis can lead to increased production costs due to culling, medication, discarded milk, delayed genetic progress, and reduced milk yield and milk quality, which combined lead to a huge economic drain on the industry (Natzke, 1981). Economic losses resulting from mastitis on a worldwide scale have been estimated to be approximately US $\$ 35$ billion (Wellenberg et al., 2002). The National Mastitis Council of the United States estimated the annual dollar loss to the dairy industry due to mastitis to be about US $\$ 2$ billion, which is equivalent to approximately $\$ 180$ per cow (Harmon, 1996). Based on the etiological agent involved, mastitis can be broadly classified into contagious mastitis (caused primarily by Staphylococcus aureus and Streptococcus agalactiae), and environmental mastitis (caused primarily by Escherichia coli, Streptococcus dysgalactiae, and Streptococcus uberis; Riffon et al., 2001). Although contagious mastitis was responsible for majority of mastitis-related losses in the past, environmental pathogens have emerged as a major concern as well. Mastitis control programs against the latter have had limited success (Pyörälä, 2002; Erskine et al., 2003).

The most common treatment method for bovine mastitis is the intramammary infusion of antibiotics. However, the cure rates obtained with antibiotic therapy are generally poor against most mastitis pathogens. For example, the cure rates of Staph. aureus infections usually vary between 20 and 78\% (Dingwell et al., 2003). Injudicious antibiotic therapy against bacterial diseases in cattle, including mastitis, has been recognized as a catalyst for emergence of antibiotic-resistant strains of bacteria (Berghash et al., 1983; Piddock, 1996; White, 1999). Moreover, use of antibiotics to treat bovine mastitis has been implicated as the most common source of harmful drug residues in milk (Erskine, 1996). Approximately $90 \%$ of the inhibitory residues detected in milk over a period of $5 \mathrm{yr}$ in Michigan originated from antibacterial therapy for mastitis (Erskine et al., 2003). Because of the previous concerns, alternatives to antibiotic therapy are being explored in an attempt to evaluate their efficacy in treating intramam- 
mary infections. These include antibacterial teat seals (Woolford et al., 1998; Ryan et al., 1999), intramammary infusion of antimicrobials such as ozone (Ogata and Nagahata, 2000), and immune modulators like $\beta 1,3$-glucan (Persson et al., 2003).

Microbicidal activity of a variety of lipids, including free fatty acids and their esters, has been studied extensively in the past. Free fatty acids and their monoglycerides were found to be inhibitory towards an array of pathogenic microorganisms including enveloped viruses, gram-positive and gram-negative bacteria (Kabara, 1978; Isaacs et al., 1995; Petschow et al., 1996). Although a plethora of information is available on the antimicrobial properties of fatty acids, most research has focused on medium- and long-chain fatty acids (containing more than 10 carbons). Caprylic acid (octanoic acid) is an 8-carbon, short-chain fatty acid naturally present in breast milk, bovine milk, and coconut oil (Jensen et al., 1990; Sprong et al., 2001; Jensen, 2002). Caprylic acid and its monoglyceride, monocaprylin, were found to be effective in inactivating infant pathogens such as herpes simplex virus, respiratory syncytial virus, Haemophilus influenzae, and Group B streptococci (Isaacs et al., 1995).

The present study was carried out to evaluate the potential application of treating bovine intramammary infections by applying caprylic acid and monocaprylin to inactivate the common bacterial mastitis pathogens in milk.

\section{MATERIALS AND METHODS}

\section{Maintenance and Preparation of Bacterial Cultures}

Three isolates each of Strep. agalactiae, Strep. dysgalactiae, Strep. uberis, Staph. aureus, and E. coli, all isolated from clinical cases of bovine mastitis at the Diagnostic Testing Services Laboratory, University of Connecticut, were used in the study. All bacteriological media used in the study were purchased from Difco (Sparks, MD). Cultures were maintained on tryptic soy agar (TSA) slants at $4^{\circ} \mathrm{C}$, and the purity of each culture was ensured by characteristic morphology on mannitol salt agar (Staph. aureus), sorbitol MacConkey agar ( $E$. coli), or blood agar (streptococci). For preparation of inocula, each isolate of the pathogen was grown separately in $10 \mathrm{~mL}$ of tryptic soy broth for $24 \mathrm{~h}$ at $37^{\circ} \mathrm{C}$. The cells were then sedimented by centrifugation (3600 $\times g$ for $15 \mathrm{~min}$ at $4^{\circ} \mathrm{C}$ ), washed twice with sterile PBS (pH 7.2), and resuspended in PBS. Equal portions from each of the 3 isolates were combined to make a 3-isolate mixture of each species of the pathogen. The bacterial population in the individual isolates and in the 3 -isolate mixture of bacteria was determined by plating $0.1-\mathrm{mL}$ portions of appropriate dilutions on TSA plates, and incubating the plates at $37^{\circ} \mathrm{C}$ for $24 \mathrm{~h}$. Appropriate dilutions of the 3-isolate mixture in PBS were used to obtain the desired level of inoculum.

\section{Lipids}

Caprylic acid and monocaprylin were purchased from Sigma (St. Louis, MO). The lipids were dissolved in dimethyl sulfoxide (DMSO; Fisher Scientific Co., Pittsburgh, PA) before adding to milk to get a final concentration of 50 and $100 \mathrm{mM}$ of caprylic acid, and 25 and $50 \mathrm{~m} M$ of monocaprylin. Concentrations of caprylic acid and monocaprylin were selected based on our previous research on the bactericidal concentration of these lipids on E. coli O157:H7 and Listeria monocytogenes in milk (Nair et al., 2004). The final concentration of DMSO in milk was always $2 \%$, which did not affect bacterial viability (Isaacs et al., 1995).

\section{Sample Preparation}

Fresh, antibiotic residue-free, raw milk was collected from the bulk tank at the University of Connecticut dairy, and autoclaved at $121^{\circ} \mathrm{C}, 103.4 \mathrm{kPa}$ of pressure for $15 \mathrm{~min}$. Appropriate amounts of caprylic acid and monocaprylin dissolved in $200 \mu \mathrm{L}$ of DMSO were added to separate tubes containing $9.8 \mathrm{~mL}$ of whole milk to obtain the aforementioned final concentrations. All milk samples were inoculated separately with $100 \mu \mathrm{L}$ of the 3-isolate mixture of each pathogen to obtain an inoculation density of approximately $7.0 \mathrm{log} \mathrm{cfu} / \mathrm{mL}$. Control samples were prepared by inoculating $100 \mu \mathrm{L}$ of the bacterial culture into $9.8 \mathrm{~mL}$ of milk containing $200 \mu \mathrm{L}$ of DMSO (DMSO control) or no DMSO (milk control). All treatment and control milk samples were incubated at $39^{\circ} \mathrm{C}$ (normal body temperature of cattle).

\section{Enumeration of Bacteria}

Surviving populations of each bacterial pathogen were enumerated at $0 \mathrm{~min}, 1 \mathrm{~min}, 6 \mathrm{~h}, 12 \mathrm{~h}$, and $24 \mathrm{~h}$ by plating $0.1-\mathrm{mL}$ portions of the milk samples directly or after serial dilutions (1:10 in PBS) on duplicate TSA plates containing $0.6 \%$ yeast extract. When the pathogens under study were not detected by direct plating, the samples were tested for surviving bacteria by enriching $1 \mathrm{~mL}$ of milk sample in $100 \mathrm{~mL}$ of tryptic soy broth at $37^{\circ} \mathrm{C}$ for $24 \mathrm{~h}$. When growth was observed in the broth, the culture was streaked on mannitol salt agar (Staph. aureus), sorbitol MacConkey agar (E. coli), or blood agar (streptococci) and observed for typical colonies of each pathogen. Duplicate samples were assayed for each treatment and control at each concentration at each specified sampling time, and the study was replicated 3 times. 


\section{Statistical Analyses}

For each analysis, data from 3 independent replicate trials in duplicate were analyzed using the GLM procedure (SAS Inst, Inc., Cary, NC). For each pathogen (Strep. agalactiae, Strep. dysgalactiae, Strep. uberis, Staph. aureus, and E. coli), the model included the 3 replicates, 5 treatments (control, caprylic acid at 50 and $100 \mathrm{~m} M$, and monocaprylin at 25 and $50 \mathrm{mM})$, time ( 0 , $1,6,12$, and $24 \mathrm{~h}$ ), and all the interactions of treatment and time. The model equation used was: model bacterial count $=$ replicate, treatment, time, and treatment $\times$ time. The degrees of freedom associated with each source were as follows; replication $=2$, treatment $=4$, time $=4$, time $\times$ treatment $=16$, error $=123$, and total $=$ 149. Least significant difference test was used to determine significant differences $(P<0.05)$ with appropriate corrections for multiple comparisons due to replication, treatment, and time on bacterial counts for each pathogen.

\section{RESULTS}

Antimicrobial activity of caprylic acid and monocaprylin against the mastitis pathogens was evaluated in autoclaved milk because of the lack of an effective selective medium for specifically enumerating the various streptococci. The average $\mathrm{pH}$ of milk before adding caprylic acid or monocaprylin was 6.6. The $\mathrm{pH}$ of milk containing $2 \%$ DMSO, $25 \mathrm{mM}$ or $50 \mathrm{~m} M$ of monocaprylin did not vary from that of normal milk. Addition of 50 and $100 \mathrm{mM}$ of caprylic acid reduced the $\mathrm{pH}$ of milk to 5.51 and 5.4, respectively.

Caprylic acid and monocaprylin reduced $(P<0.05)$ the counts of all the 5 pathogens compared with control samples. Effect of caprylic acid and monocaprylin on the 3 streptococci species in milk was similar (Figures 1,2 , and 3 ). The average initial population of the pathogens at $0 \mathrm{~min}$ in all samples was approximately $7.0 \mathrm{log}$ $\mathrm{cfu} / \mathrm{mL}$. Caprylic acid at $100 \mathrm{mM}$ and monocaprylin at $50 \mathrm{~m} M$ killed the pathogens rapidly, reducing Strep. agalactiae, Strep. dysgalactiae, and Strep. uberis by approximately $5.0 \mathrm{log} \mathrm{cfu} / \mathrm{mL}$ following $1 \mathrm{~min}$ of incubation. After $6 \mathrm{~h}$ of incubation, the population of the 3 species of streptococci in all treatment samples was reduced to less than $1.0 \log \mathrm{cfu} / \mathrm{mL}$ (detected by enrichment), without substantial, further reduction after 24 h. In control samples containing no caprylic acid or monocaprylin, Strep. agalactiae, Strep. dysgalactiae, and Strep. uberis grew slightly by $6 \mathrm{~h}$, with no further increase in their population at the end of $24 \mathrm{~h}$ (Figures 1,2 , and 3 ).

The effect of caprylic acid and monocaprylin on the viability of Staph. aureus in milk is depicted in Figure 4. Among the 4 treatments, $100 \mathrm{~m} M$ caprylic acid and
$50 \mathrm{~m} M$ monocaprylin were most effective in reducing Staph. aureus. After 1 min of incubation, these 2 treatments reduced the population of Staph. aureus by $>2$ $\log \mathrm{cfu} / \mathrm{mL}$. After $6 \mathrm{~h}$, the population of Staph. aureus decreased by more than $5.0 \log \mathrm{cfu} / \mathrm{mL}$ in all treatment samples, without further reduction after $24 \mathrm{~h}$. In contrast, in the samples containing $100 \mathrm{~m} M$ caprylic acid or $50 \mathrm{mM}$ monocaprylin, Staph. aureus was reduced to less than $1.0 \mathrm{log} \mathrm{cfu} / \mathrm{mL}$ by $24 \mathrm{~h}$ (Figure 4 ). In the control samples devoid of caprylic acid or monocaprylin, the population of Staph. aureus increased to approximately $8.0 \mathrm{log} \mathrm{cfu} / \mathrm{mL}$ after $24 \mathrm{~h}$ of incubation.

Similar to the results observed with streptococci and Staph. aureus, both caprylic acid and monocaprylin were effective in killing $E$. coli in milk (Figure 5). Among the 4 treatments tested, $100 \mathrm{~m} M$ caprylic acid and 50 $\mathrm{m} M$ monocaprylin were most effective, with the former reducing $E$. coli populations by approximately $5.0 \mathrm{log}$ $\mathrm{cfu} / \mathrm{mL}$ after 1 min of incubation (Figure 5). Both of these treatments decreased $E$. coli counts to approximately $1.0 \log \mathrm{cfu} / \mathrm{mL}$ after $24 \mathrm{~h}$ of incubation, whereas in the milk samples containing less caprylic acid or monocaprylin, the pathogen tended to recover and grow back, resulting in a final count of approximately $2.0 \mathrm{log}$ cfu/mL (Figure 5). The population of $E$. coli in the control samples increased by approximately $1.0 \mathrm{log} \mathrm{cfu} /$ $\mathrm{mL}$ after $24 \mathrm{~h}$ incubation. Throughout the study, the population of inoculated pathogens at any of the sampling periods did not differ between controls with and without $2 \% \mathrm{DMSO}$, indicating that DMSO had no inhibitory effect on bacterial cells at the concentration used. Because adding $100 \mathrm{~m} M$ caprylic acid reduced the $\mathrm{pH}$ of milk to 5.40, we determined the viability of the pathogens in milk at $\mathrm{pH} 5.40$ to rule out any potential inhibitory effect of the low $\mathrm{pH}$ on the bacteria. Results revealed that none of the pathogens was inactivated in the milk samples at $\mathrm{pH} 5.4$ after $24 \mathrm{~h}$ of incubation at $39^{\circ} \mathrm{C}$ (data not shown).

\section{DISCUSSION}

Although fatty acids have been exploited for centuries as antimicrobials in soaps, the antimicrobial properties of individual fatty acids received little attention before the 1930s (Sun et al., 2002). A substantial body of literature exists on the antimicrobial properties of free fatty acids and their esters in various synthetic laboratory media (Hogan et al., 1987; Wang and Johnson, 1992; Petschow et al., 1996), but their efficacy in killing bacteria in milk or in a menstruum with a high organic content is limited. For example, Wang and Johnson (1992) investigated the antimicrobial effect of a variety of fatty acids $\left(\mathrm{C}_{12: 0}, \mathrm{C}_{14: 0}, \mathrm{C}_{16: 0}, \mathrm{C}_{18: 0}, \mathrm{C}_{18: 1}, \mathrm{C}_{18: 2}\right.$, and $\mathrm{C}_{18: 3}$ ), and monoglycerides of lauric acid (monolaurin), 


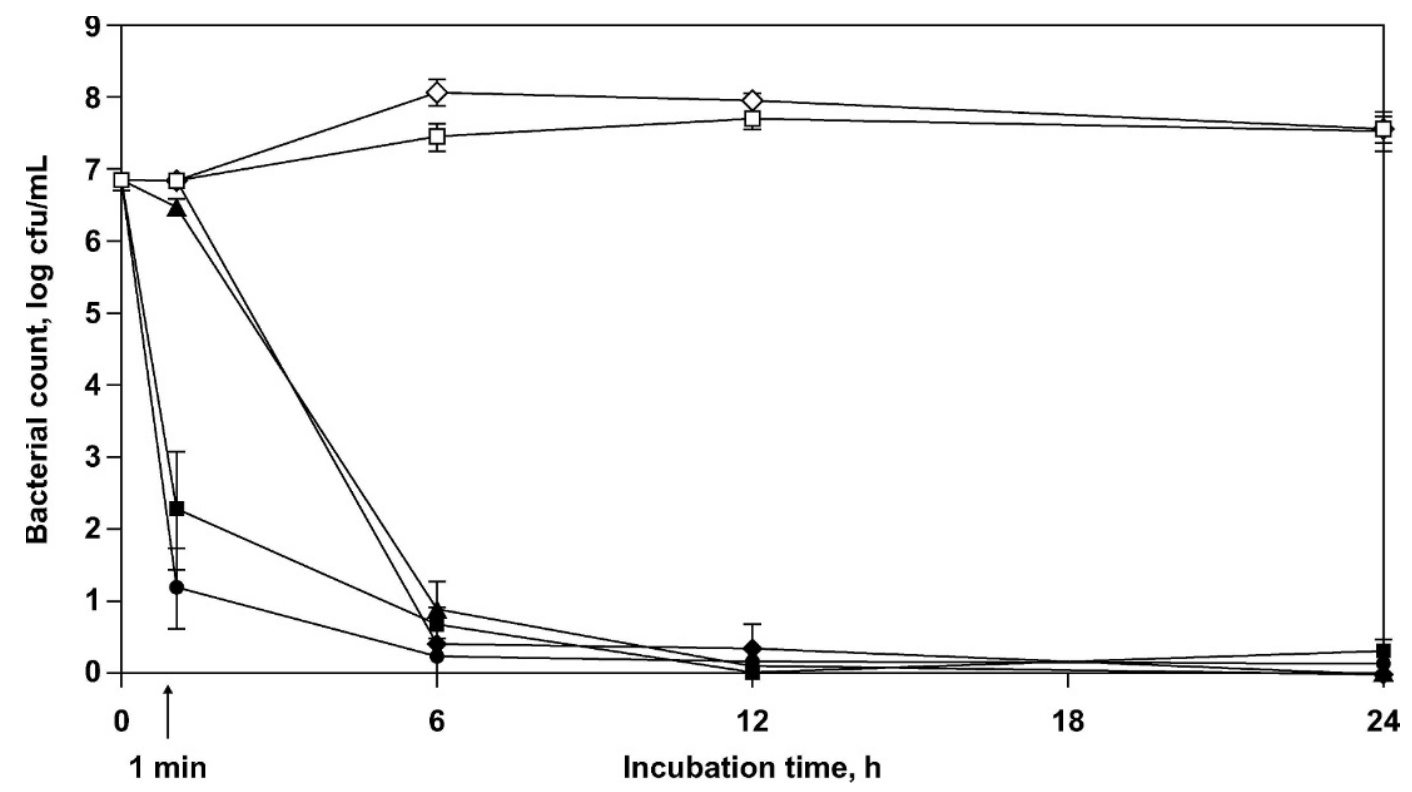

Figure 1. Effect of caprylic acid and monocaprylin on Streptococcus agalactiae in milk containing ( $) 50 \mathrm{~m} M$ caprylic acid, ( $\square) 100 \mathrm{~m} M$

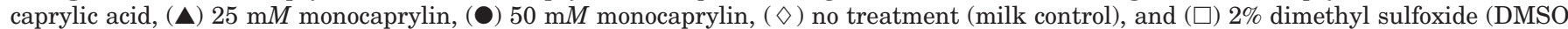
control). Surviving bacterial populations (expressed in log cfu/mL) in milk samples stored at $39^{\circ} \mathrm{C}$ for $24 \mathrm{~h}$ were enumerated at specified time points on tryptic soy agar plates containing $0.6 \%$ yeast extract.

myristic acid, and palmitic acid against Listeria monocytogenes in brain-heart infusion broth and milk. These researchers found that although $\mathrm{C}_{12: 0}, \mathrm{C}_{14: 0}$, and monolaurin were bactericidal in brain-heart infusion broth, none of the fatty acids or monolaurin was inhibitory on L. monocytogenes in milk. Reduced antimicrobial activity of fatty acids and monoglycerides observed in milk has been attributed to its complex composition

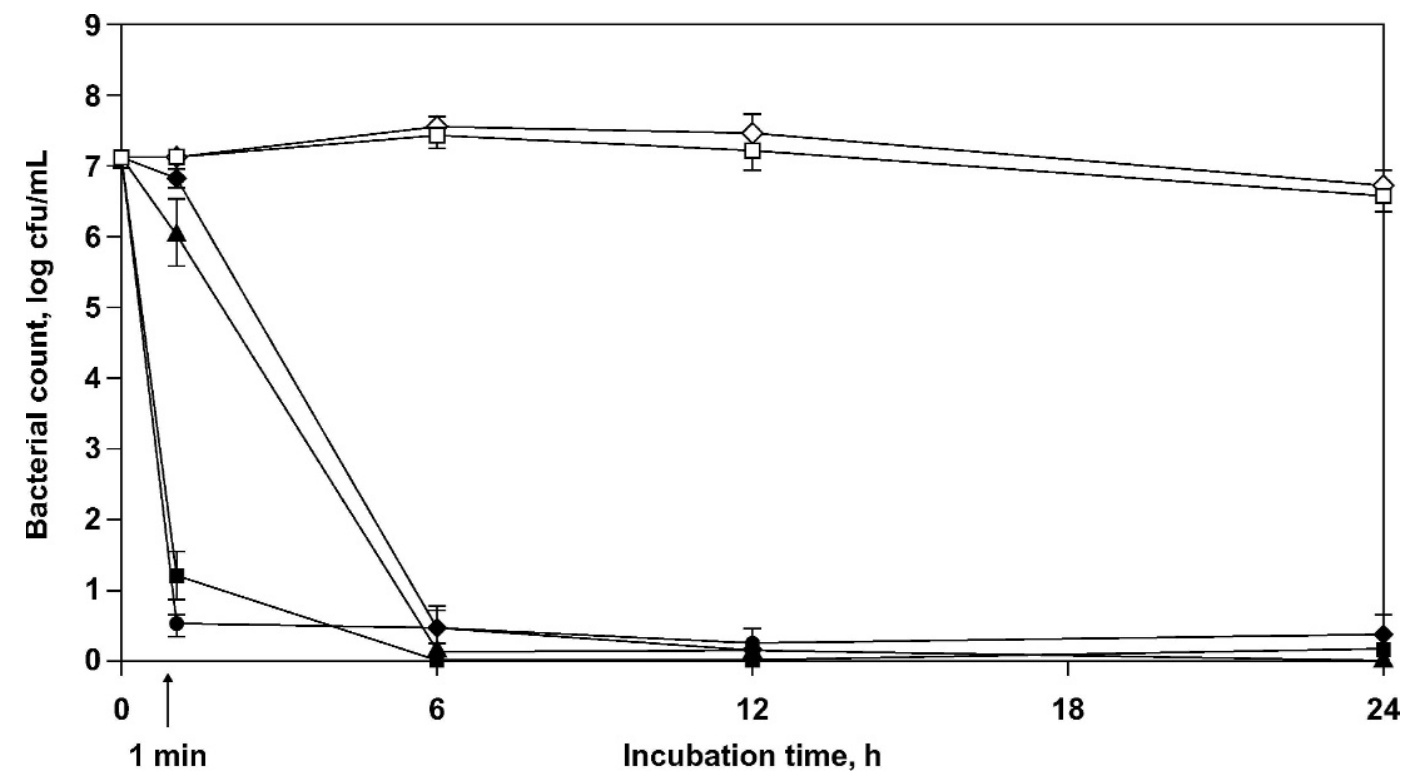

Figure 2. Effect of caprylic acid and monocaprylin on Streptococcus dysgalactiae in milk containing ( $\bullet$ ) $50 \mathrm{~m} M$ caprylic acid, ( $\mathbf{\square}) 100$

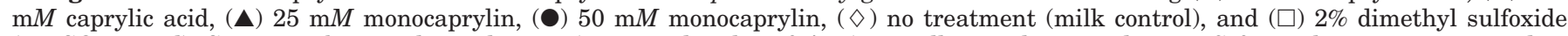
(DMSO control). Surviving bacterial populations (expressed in $\log \mathrm{cfu} / \mathrm{mL}$ ) in milk samples stored at $39^{\circ} \mathrm{C}$ for $24 \mathrm{~h}$ were enumerated at specified time points on tryptic soy agar plates containing $0.6 \%$ yeast extract. 


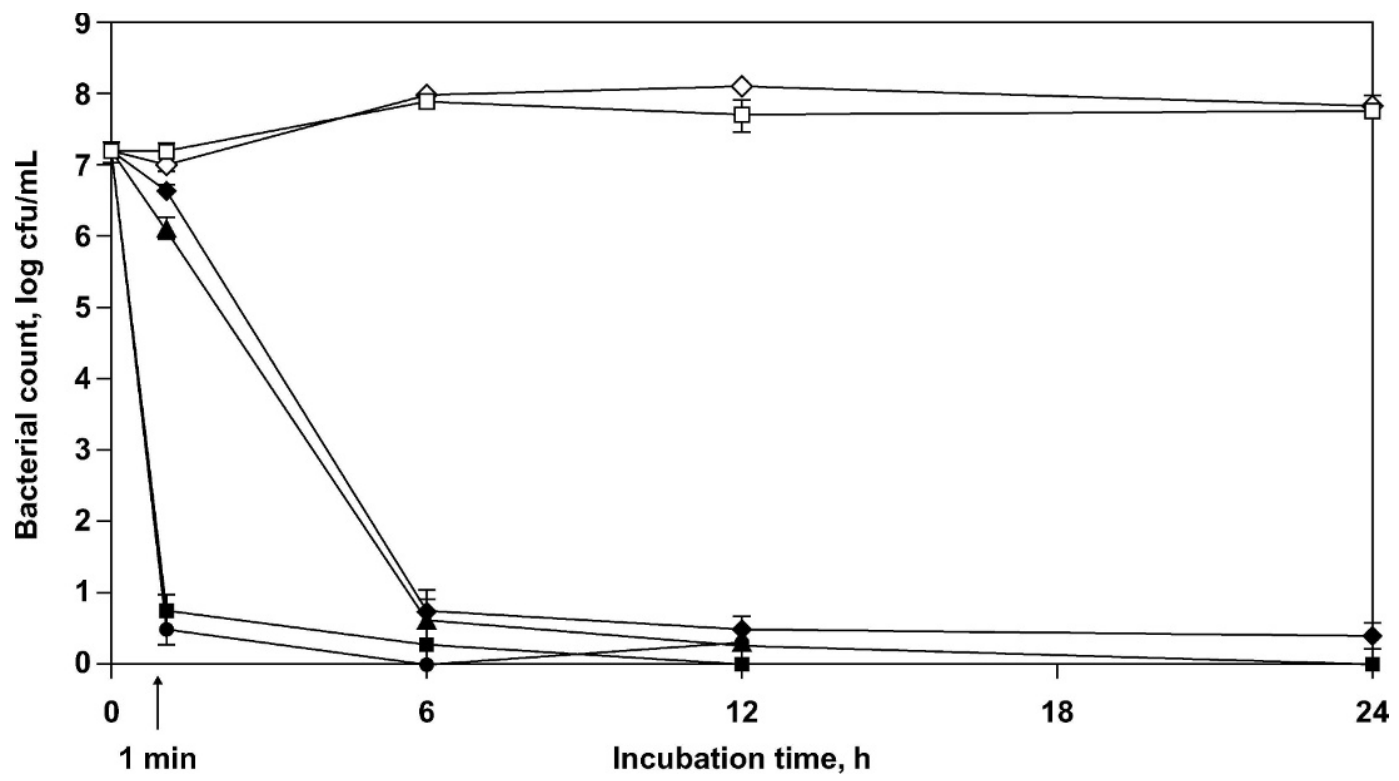

Figure 3. Effect of caprylic acid and monocaprylin on Streptococcus uberis in milk containing ( $) 50 \mathrm{~m} M$ caprylic acid, (ם) $100 \mathrm{~m} M$

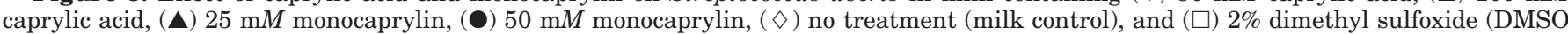
control). Surviving bacterial populations (expressed in log cfu/mL) in milk samples stored at $39^{\circ} \mathrm{C}$ for $24 \mathrm{~h}$ were enumerated at specified time points on tryptic soy agar plates containing $0.6 \%$ yeast extract.

(Wang and Johnson, 1992). Proteins, especially lipophilic proteins such as albumin, and other nutrients, including fat and starch, interact with fatty acids and monoglycerides, thereby reducing their bioavailability
(Kabara, 1978). Glassman (1949) reported that proteins reduce the bactericidal activity of surface-active agents like monoglycerides due to the formation of lipid-protein complexes. However, results of this study indicate

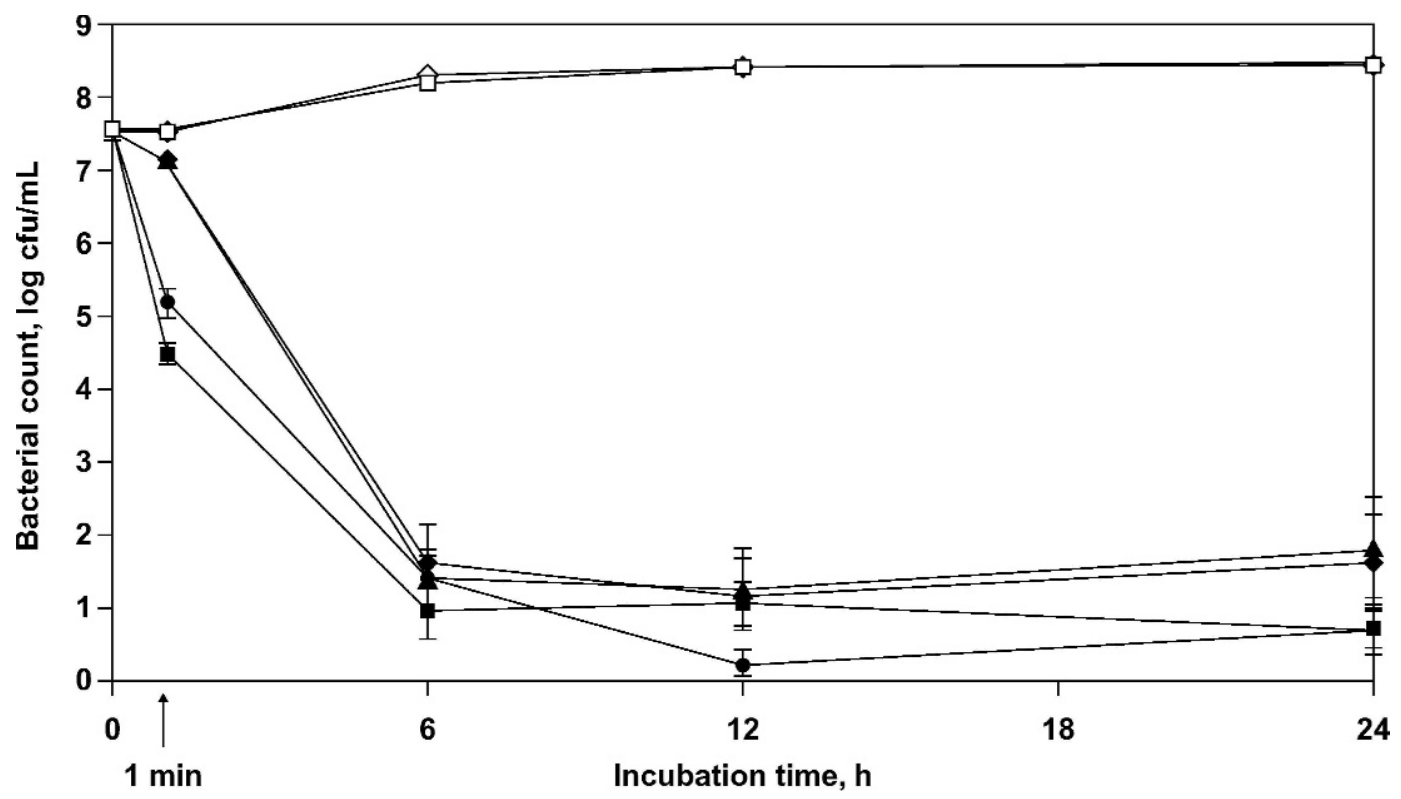

Figure 4. Effect of caprylic acid and monocaprylin on Staphylococcus aureus in milk containing ( $\bullet 50 \mathrm{~m} M$ caprylic acid, (ロ) $100 \mathrm{~m} M$

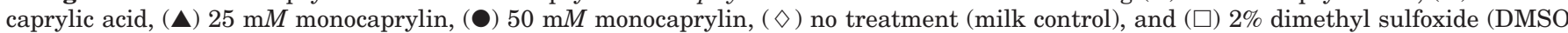
control). Surviving bacterial populations (expressed in log cfu/mL) in milk samples stored at $39^{\circ} \mathrm{C}$ for $24 \mathrm{~h}$ were enumerated at specified time points on tryptic soy agar plates containing $0.6 \%$ yeast extract. 


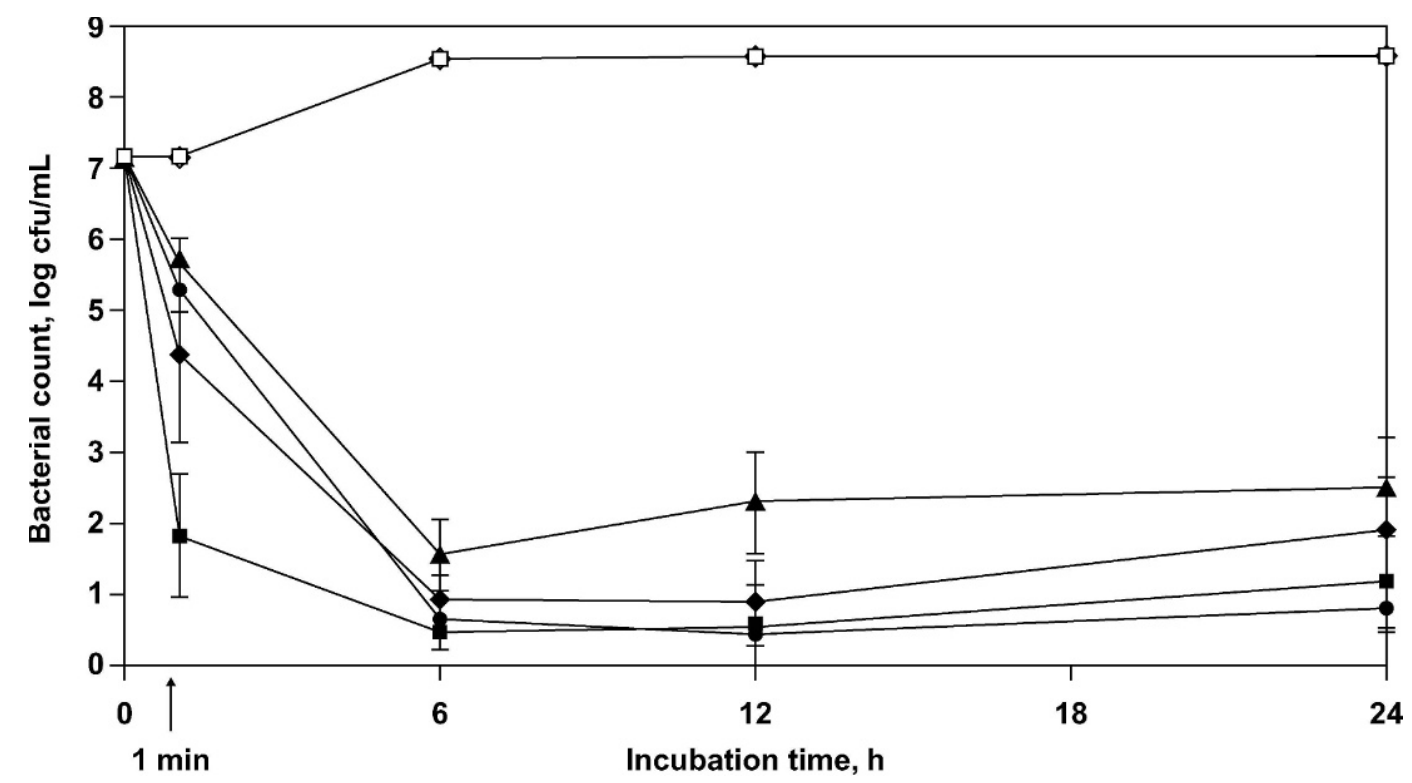

Figure 5. Effect of caprylic acid and monocaprylin on Escherichia coli in milk containing ( $) 50 \mathrm{~m} M$ caprylic acid, ( $\mathbf{\square}) 100 \mathrm{~m} M$ caprylic

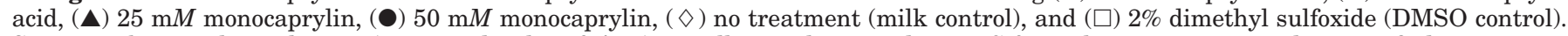
Surviving bacterial populations (expressed in log cfu/mL) in milk samples stored at $39^{\circ} \mathrm{C}$ for $24 \mathrm{~h}$ were enumerated at specified time points on tryptic soy agar plates containing $0.6 \%$ yeast extract.

that both caprylic acid and monocaprylin were effective in killing the 5 mastitis pathogens in milk. Moreover, preliminary experiments conducted in our laboratory revealed that the antibacterial effect of caprylic acid and monocaprylin in raw and autoclaved milk did not differ significantly (data not shown). We have used DMSO as a solvent for monocaprylin in this study and have previously observed that in addition to DMSO, ethanol (2\%) could also be used as an effective solvent for dissolving monocaprylin in milk (Nair et al., 2004). The pronounced antimicrobial effect of caprylic acid and monocaprylin on bacteria observed in the present study could be partly attributed to its short chain length. The antimicrobial property of fatty acids decreases with increasing chain length, with medium-chain fatty acids exhibiting stronger activity than longer-chain fatty acids (Wang and Johnson, 1992). Similarly, Isaacs et al. (1995) reported that fatty acids and monoglycerides containing 8 to 12 carbons were more antiviral and antibacterial than their longer-chain counterparts. Galbraith et al. (1971) noted that fatty acids must be in solution and remain sufficiently lipophilic to enable adsorption to bacterial cell surfaces for antibacterial activity. Caprylic acid being an 8-carbon, short-chain fatty acid, is less hydrophobic and potentially more soluble than medium-chain and long-chain fatty acids, and more effective in killing bacteria.

Among the 5 bacterial species tested in this study, Strep. agalactiae, Strep. dysgalactiae, and Strep. uberis were most sensitive to caprylic acid and monocaprylin in milk. In general, caprylic acid at $100 \mathrm{~m} M$ and monocaprylin at $50 \mathrm{~m} M$ levels resulted in a rapid decline (4 to $6 \log \mathrm{cfu} / \mathrm{mL}$ ) in the populations of streptococci after 1 min of treatment. At the same time point, the effect of monocaprylin on E. coli and both caprylic acid and monocaprylin on Staph. aureus was less pronounced. Differences in the instantaneous antibacterial effect of these lipids on various pathogens could be attributed to the difference in their cell surface properties. Most mastitis-causing strains of Staph. aureus are surrounded by a layer of exopolysaccharide or pseudocapsule slime (Sutra et al., 1990), which could interfere with the lipids coming in direct contact with the bacterial cell membranes and exert their antimicrobial activity. The 3 Staph. aureus isolates used in the study were found to produce slime when grown on Congo red agar plates (data not shown). Similarly, Butcher et al. (1976) reported that long-chain fatty acids were generally more inhibitory to hemolytic streptococci than Staph. aureus. In comparison with the other 4 bacterial species, $E$. coli is a gram-negative mastitis pathogen, and differences in the cell wall structure could have contributed to the comparatively lesser effect of the lipids on $E$. coli. Other investigators also have reported that gramnegative bacteria are less sensitive to the antimicrobial effect of fatty acids and monoglycerides than gram-positive bacteria (Kabara, 1978; Monk et al., 1996). 
Although the exact mechanism of action of caprylic acid and monocaprylin on bacteria is not known, numerous hypotheses have been suggested to explain the general mode of antimicrobial activity of free fatty acids and their monoglycerides. One theory maintains that monoglycerides as nonionic surfactants penetrate and are incorporated into bacterial plasma membrane, thereby altering membrane permeability. Electron microscopic studies with bacterial cells exposed to monoglycerides have shown plasma membrane disintegration leaving the peptidoglycan cell wall intact (Bergsson et al., 1998). Another school of thought hypothesizes that short- and medium-chain fatty acids diffuse into bacterial cells in their undissociated form and dissociate within the protoplasm, thereby leading to intracellular acidification (Sun et al., 1998). A lower intracellular $\mathrm{pH}$ can lead to inactivation of intracellular enzymes (Viegas and Sa-Correia, 1991), and inhibition of amino acid transport (Freese et al., 1973). At sublethal concentrations, monoglycerides such as monolaurin can interfere with bacterial signal transduction, and inhibit the expression of virulence factors and antibiotic resistance genes (Projan et al., 1994; Ruzin and Novick, 1998).

Emergence of antimicrobial resistant strains of animal pathogens and their potential health risk to humans through foodborne transmission have engaged the attention of the public and scientific community. Because of the extensive use of antibiotics, many gramnegative pathogens such as E. coli and Salmonella spp. were found to acquire multiple drug-resistance genes that restrict treatment options (White, 1999). The pressure to limit antibiotic use in food-producing animals is one of the biggest challenges for the dairy industry, even though antibiotics remain the most effective tool to combat mastitis (Bradley, 2002). Therefore, a need exists for an effective, alternative strategy for treating bovine mastitis that would reduce the use of antibiotics. Because fatty acids and their monoglycerides are believed to kill bacteria by multiple mechanisms, the potential for developing bacterial resistance to these molecules is relatively negligible. Bergsson et al. (1999) suggested that free fatty acids and monoglycerides exert their antimicrobial effect on bacterial biological membranes; thus, the chances of emergence of bacterial resistance are very unlikely. Petschow et al. (1996) observed relatively lower frequency of resistance development in Helicobacter pylori against C-10 and C-12 monoglycerides and C-12 fatty acids compared with other common antimicrobials tested. Fatty acids and their monoglycerides, being present in natural secretions such as milk are assumed, at least in smaller concentrations, to be nontoxic to mucosa (Bergsson et al., 1998). Caprylic acid is a food-grade chemical approved by the Food and Drug Administration as Gener- ally Regarded as Safe (GRAS 184.1025). Toxicity studies have shown that caprylic acid is nontoxic even at large concentrations, with an oral $\mathrm{LD}_{50}$ of $10.1 \mathrm{~g}$ of caprylic acid per kg of BW in rats (Jenner et al., 1964).

In conclusion, caprylic acid and monocaprylin at the concentrations tested were bactericidal against the major bovine mastitis pathogens Strep. agalactiae, Strep. dysgalactiae, Strep. uberis, Staph. aureus, and E. coli in milk. These results provide justification for evaluation of caprylic acid and monocaprylin as alternatives or adjuncts to antibiotics for treatment of bovine mastitis. Future experiments are needed, however, to ascertain the in vivo efficacy of these lipid molecules as an intramammary treatment of bovine mastitis, and their potential effects on the mammary gland tissue.

\section{REFERENCES}

Berghash, S. R., J. N. Davidson, J. C. Armstrong, and G. M. Dunny. 1983. Effects of antibiotic treatment of nonlactating dairy cows on antibiotic resistance patterns of bovine mastitis pathogens. Antimicrob. Agents Chemother. 24:771-776.

Bergsson, G., J. Arnfinnsson, S. M. Karlsson, O. Steingrimsson, and H. Thormar. 1998. In vitro inactivation of Chlamydia trachomatis by fatty acids and monoglycerides. Antimicrob. Agents Chemother. 42:2290-2294.

Bergsson, G., O. Steingrimsson, and H. Thormar. 1999. In vitro susceptibilities of Neisseria gonorrhoeae to fatty acids and monoglycerides. Antimicrob. Agents Chemother. 43:2790-2792.

Bradley, A. J. 2002. Bovine mastitis: An evolving disease. Vet. J. 164:116-128.

Butcher, G. W., G. King, and K. G. Dyke. 1976. Sensitivity of Staphylococcus aureus to unsaturated fatty acids. J. Gen. Microbiol. 94:290-296

Dingwell, R. T., K. E. Leslie, T. F. Duffield, Y. H. Schukken, L. DesCoteaux, G. P. Keefe, D. F. Kelton, K. D. Lissemore, W. Shewfelt, P. Dick, and R. Bagg. 2003. Efficacy of intramammary tilmicosin and risk factors for cure of Staphylococcus aureus infection in the dry period. J. Dairy Sci. 86:159-168.

Erskine, R. J. 1996. Why do antibiotic residues in milk happen? Michigan Dairy Rev. 1:16.

Erskine, R. J., S. Wagner, and F. J. DeGraves. 2003. Mastitis therapy and pharmacology. Vet. Clin. North Am. Food Anim. Pract. 19:109-138.

Freese, E., C. W. Sheu, and E. Galliers. 1973. Function of lipophilic acids as antimicrobial food additives. Nature 241:321-325.

Galbraith, H., T. B. Miller, A. M. Paton, and J. K. Thompson. 1971. Antibacterial activity of long chain fatty acids and the reversal with calcium, magnesium, ergocalciferol and cholesterol. J. Appl. Bacteriol. 34:803-813.

Glassman, H. N. 1949. Surface active agents and their application in bacteriology. Bacteriol. Rev. 12:105-148.

Harmon, R. J. 1996. Controlling contagious mastitis. Page 11 in Natl. Mastitis Council, Reg. Mtg. Proc., Queretero, Mexico. Natl. Mastitis Council, Inc., Madison, WI.

Hogan, J. S., J. W. Pankey, and A. H. Duthie. 1987. Growth inhibition of mastitis pathogens by long-chain fatty acids. J. Dairy Sci. 70:927-934.

Isaacs, C. E., R. E. Litov, and H. Thormar. 1995. Antimicrobial activity of lipids added to human milk, infant formula, and bovine milk. J. Nutr. Biochem. 6:362-366.

Jenner, P., E. Hagan, J. Taylor, E. Cook, and O. Fitzhugh. 1964. Food flavorings and compounds of related structure: Acute oral toxicity. Food Cosmet. Toxicol. 2:327-343.

Jensen, R. G. 2002. The composition of bovine milk lipids: January 1995 to December 2000. J. Dairy Sci. 85:295-350. 
Jensen, R. G., A. M. Ferris, C. J. Lammi-Keefe, and R. A. Henderson. 1990. Lipids of bovine and human milks: A comparison. J. Dairy Sci. 73:223-240.

Kabara, J. J. 1978. Fatty acids and derivatives as antimicrobial agents. Pages 1-14 in The Pharmacological Effect of Lipids. J. J. Kabara, ed. American Oil Chemists Society, St. Louis, MO.

Monk, J. D., L. R. Beuchat, and A. K. Hathcox. 1996. Inhibitory effects of sucrose monolaurate, alone and in combination with organic acids, on Listeria monocytogenes and Staphylococcus aureus. J. Appl. Bacteriol. 81:7-18.

Nair, M. K. M., P. Vasudevan, T. Hoagland, and K. Venkitanarayanan. 2004. Inactivation of Escherichia coli O157:H7 and Listeria monocytogenes in milk by caprylic acid and monocaprylin. Food Microbiol. 21:611-616.

Natzke, R. P. 1981. Elements of mastitis control. J. Dairy Sci. 64:1431-1442.

Ogata, A., and H. Nagahata. 2000. Intramammary application of ozone therapy to acute clinical mastitis in dairy cows. J. Vet. Med. Sci. 62:681-686.

Persson, W. K., U. Gronlund, and A. Johannisson. 2003. Intramammary infusion of $\beta 1,3$-glucan for prevention and treatment of Staphylococcus aureus mastitis. J. Vet. Med. B Infect. Dis. Vet. Public Health 50:121-127.

Petschow, B. W., R. P. Batema, and L. L. Ford. 1996. Susceptibility of Helicobacter pylori to bactericidal properties of medium-chain monoglycerides and free fatty acids. Antimicrob. Agents Chemother. 40:302-306.

Piddock, L. J. 1996. Does the use of antimicrobial agents in veterinary medicine and animal husbandry select antibiotic-resistant bacteria that infect man and compromise antimicrobial chemotherapy? J. Antimicrob. Chemother. 38:1-3.

Projan, S. J., S. Brown-Skrobot, P. M. Schlievert, F. Vandenesch, and R. P. Novick. 1994. Glycerol monolaurate inhibits the production of $\beta$-lactamase, toxic shock syndrome toxin-1, and other staphylococcal exoproteins by interfering with signal transduction. J. Bacteriol. 176:4204-4209.

Pyörälä, S. 2002. New strategies to prevent mastitis. Reprod. Domest. Anim. 37:211-216.

Riffon, R., K. Sayasith, H. Khalil, P. Dubreuil, M. Drolet, and J. Lagace. 2001. Development of a rapid and sensitive test for identi- fication of major pathogens in bovine mastitis by PCR. J. Clin. Microbiol. 39:2584-2589.

Ruzin, A., and R. P. Novick. 1998. Glycerol monolaurate inhibits induction of vancomycin resistance in Enterococcus faecalis. J. Bacteriol. 180:182-185.

Ryan, M., J. Flynn, C. Hill, R. Ross, and W. Meaney. 1999. The natural food grade inhibitor, Lacticin 3147, reduced the incidence of mastitis after experimental challenge with Streptococcus dysgalactiae in nonlactating dairy cows. J. Dairy Sci. 82:2108-2114.

Sprong, R. C., M. F. E. Hulstein, and R. van der Meer. 2001. Bactericidal activities of milk lipids. Antimicrob. Agents Chemother. 45:1298-1301.

Sun, C. Q., C. J. O'Connor, and A. M. Roberton. 2002. The antimicrobial properties of milkfat after partial hydrolysis by calf pregastric lipase. Chem. Biol. Interact. 140:85-98.

Sun, C. Q., C. J. O'Connor, S. J. Turner, G. D. Lewis, R. A. Stanley, and A. M. Roberton. 1998. The effect of $\mathrm{pH}$ on the inhibition of bacterial growth by physiological concentrations of butyric acid: Implications for neonates fed on suckled milk. Chem. Biol. Interact. 113:117-131.

Sutra, L., C. Mendolia, P. Raiard, and B. Poutrel. 1990. Encapsulation of Staphylococcus aureus isolates from mastitic milk: Relationship between capsular polysaccharide types 5 and 8 and colony morphology in serum-soft agar, clumping factor, teichoic acid and protein A. J. Clin. Microbiol. 28:447-451.

Viegas, C. A., and I. Sa-Correia. 1991. Activation of plasma membrane ATPase of Saccharomyces cerevisiae by octanoic acid. J. Gen. Microbiol. 137:645-651.

Wang, L. L., and E. A. Johnson. 1992. Inhibition of Listeria monocytogenes by fatty acids and monoglycerides. Appl. Environ. Microbiol. 58:624-629.

Wellenberg, G. J., W. H. van der Poel, and J. T. van Oirschot. 2002 Viral infections and bovine mastitis: A review. Vet. Microbiol. 88:27-45.

White, D. G. 1999. Use and misuse of antimicrobials in veterinary medicine. Page 9 in Natl. Mastitis Counc. Proc. 38th Annu. Mtg., Arlington, VA. Natl. Mastitis Counc., Inc., Madison, WI.

Woolford, M., J. Williamson, A. Day, and P. Copeman. 1998. The prophylactic effect of a teat sealer on bovine mastitis during the dry period and the following lactation. N.Z. Vet. J. 46:12-19. 